\title{
SDG's Goal Concepts For Sustainability Development On Accountants' Perspective In Energy Aspect: Evidence From Indonesia
}

\author{
Sailendra ${ }^{1}$ \\ ${ }^{1}$ Universitas Pancasila, Jakarta, Indonesia
}

\section{INFO ARTIKEL JEL Classification :}

Q56, Q01

\section{Keywords :}

sdgs, accountants' perspective, sustainability, energy

\begin{abstract}
This study achievement is to obtain accountants' perspective in developments in energy. Sample of this study is an accountant with a minimum of five years working experiences in the management and senior manager level working in Indonesia companies and government. This research questions adopted four scale Likert methods. Data collected from respondents participated in this study using online Google form and manual survey method, both online and manual data received from respondents combined into one spreadsheet using excel Microsoft program for future analysis. Total data validity and reliability accepted is that 36 samples tested by SPSS statistic software version 22. Base on the sample received, descriptive statistics analysis shown that average $51 \%$ of accountants understand about energy and $61 \%$ says that energy sustainability is crucial from their side view. Encourage of energy calculated as part of the accounting system and disclose in the company annual report, also suggested.
\end{abstract}

\section{ABSTRAK}

Penelitian ini bertujuan untuk mengetahui perspektif akuntan terhadap aspek energi berdasarkan konsep tujuan SDGs untuk pengembangan keberlanjutan terhadap energi. Sampel penelitian adalah akuntan dengan pengalaman kerja minimal lima tahun di level manajemen dan manajer senior yang bekerja di perusahaan dan pemerintah Indonesia. Pertanyaan penelitian mengadopsi empat metode skala Likert. Data yang dikumpulkan dari responden yang berpartisipasi dalam penelitian ini menggunakan google online form dan metode survei manual, baik data online maupun manual yang diterima dari responden digabungkan menjadi satu spreadsheet menggunakan program Microsoft excel untuk dilakukan analisis. Total validitas dan reliabilitas data yang diterima sebanyak 36 sampel yang diuji menggunakan program statistik SPSS versi 22. Berdasarkan sampel yang diterima, analisis statistik deskriptif menunjukkan bahwa rata-rata $51 \%$ akuntan memahami tentang energi dan $61 \%$ menyatakan bahwa keberlanjutan energi sangat penting dari sisi pandangan mereka. Para akuntan juga mendorong agar energi yang digunakan pada aktifitas bisnis, merupakan bagian dari sistem akuntansi dan diungkapkan dalam laporan tahunan perusahaan, juga sangat disarankan. 


\section{Introduction}

The issue of energy crisis and sustainability currently as a hot topic around the worlds. Especially for developing countries, such as Indonesia. The plight of energy in Indonesia currently nearly showing the symptoms. In the year 2015, the Indonesian country estimated will be deficit fuel and gas production supply around 2,4 - 2,5 million BOPD and expected that's will continue for $11-12$ year more, if no other new resources found, it means Indonesian will crisis fuel and gas reserve, and then to be a net importer country" (Tempo.co, 2015), and then base on Indonesian senior economics, Faisal Basri, he predicted that Indonesia would experience an energy deficit of up to the US \$ 80 billion or around $\mathrm{Rp} 1,122$ trillion in 2040 . The prediction refers to the condition of domestic energy production and consumption that continues to show inequality (Tempo.co, 2019).

The issue of energy crisis and sustainability has an impact on all countries around the world, especially developing countries, and countries have less income. Because every year consumption of energy always increases in-line with an increase of people population and industries activities. Limited resources reserve due to decrease from year to year will have an impact into an increase in energy price, and it will barrier peoples to access energy in developing and emerging countries, decrease economics activities and human quality life. Despite progress in the year 2012, "nearly 1.3 billion people remain without access to electricity, and 2.6 billion do not have access to clean cooking facilities" (WEO, 2012).

Until now, most countries in the world their peoples still using conventional energy. Using fossil fuels for energy causes carbon emissions linked to climate change (Dwyer, 2011) and also now fossil energy is limited resources reserve in the world (Narbel, 2014). Activities to produce and get the energy, most potential to impact environment damage if not well manage and well developed by energy producer. Because every people and industry need energy for their life activities to increase life quality and sustainable, but still many peoples in the poor and developing countries no access to affordable, reliable, sustainable and modern energy to improve their quality of life.

Accountants involve in energy to make sure and highlights the issue of energy and organisations must address to make sustainability an integral part of corporation business model for future corporate and human life quality and sustainability, because "Fossil fuel is limited resources, and also fossil fuel are non-renewable resources and therefore represent a limited sources of energy" (Narbel, 2014). Sustainability Energy as a concept to managing and build the countries with considering energy efficiencies and economical energy factor, "the world must reduce energy consumption to build a sustainable society" (Gyberg \& Palm, 2009) and according to (Krajnic, Lukman, \& Glavic, 2008), "our world might not be able to achieve sustainable development if the overall energy consumption pattern remains unchanged". In reality, many accountants involved in the management accountants, internal auditor and public accountants were engaged in the energy audit (Roth, 2008) process and costs allocating for the company and public activities. It is means accountant in the circle of energy process, manage, calculating, allocations and reporting. The Professional Accountant in Business (FASB) and Committee of the International Federation of Accountant (IFAC) have developed a comprehensive sustainability framework to support professional accountants and their organisations in integrating a sustainable way of thinking and working in all business process. Energy is crucial for human life, economics and company sustainability, where is an accountant as part of there. Sustainable Development is the concept of considering economic factor, social and environment commonly knowing as "Sustainability Development Goals" (SGDs) concept. This concept was starting from concerning finance ministries and Governor of Central Bank of developing countries about the financial crisis in Asia for the year 1997 - 1998, then well known as G20 group. Otherwise, the only country with the financial resources to develop business activities leading to significant growth of the economy (Ahmad, 2011).

Secretary-General of Rio +20 in the formal UNCD leaflet says "Sustainable development is 
not an option. It is the only path that allows all of humanity to share a decent life on this one planet. Rio +20 allows our generation to choose this path". Meanwhile, Secretary-General of United Nation Ban Ki-moon, to stressing urgently of SDGs for future of earth and peoples. His statement "our vision must be clear: a sustainable green economy that protects the health of the environment while supporting the achievement of the millennium development goals through in income, decent work, and poverty eradication." Moreover, also with Indonesia give his commitment to joining and support of the implementation of SDGs as presented by $\mathrm{Mr}$ Yudhoyono as President of the Republic of Indonesia at that time, he said "we in the region remain firmly committed and determined to attain our MDGs. We are mobilising regional resources and initiatives, such as the Asian Development Bank and the Association of Southeast Asian Nations, to help us toward those Goals".

The commitment to the implementation of the SDGs concept needs to support from all countries and peoples come from all professions to make the peoples in the countries more better life in the future. By increasing economic value with energy to building they countries and harmonies with the environment, will increase peoples income and quality of life, and sustainability, because "if companies continue to exploit non-renewable energy, the environment is also likely to suffer." (Gunawan, Djajadikerta, \& Smith, 2009).

Energy consumption has a direct effect on operational costs and increases exposure to the fluctuation of energy supply and prices. The environmental footprint of an organisation is shaped in part by its choice of energy sources. Changes in the balance of these sources can indicate the organisation's efforts to minimise its environmental impacts. There is some "huge difference between companies in the same industries in applying accounting principles, rule, methods and procedure" (Ahmad \& Gao, 2007) but it indicated that all companies aware of their social responsibility, especially for environmental and communities issues (Ahmad, 2011).

Energy access is about providing modern energy services for every person around the world. The services defined as household access to electricity and clean cooking facilities, i.e., fuel and stoves, do not produce air pollution in the house. According to IEA reporting in $201138 \%$ or around 2.6 billion people of global population lack to clean cooking facilities and $18 \%$ or 1.3 billion peoples lack access to electricity, more than $85 \%$ of these people are living in SaharanAfrican and developing Asia and 84\% in rural areas. Ten counties account for two-thirds of those without electricity and just three countries; India, China and Bangladesh account for more than half of those without clean cooking facilities, and Indonesia country $27 \%$ without access to electricity and $55 \%$ still using traditional of biomass for cooking (WEO, 2012). The environmental and energy accounting, which has developed as a rich and diverse arena were broader context of social for practice and research over the past four decade (Ascui \& Lovell, 2011; R. Gray, Bebbington, \& Walters, 1993; Rob Gray, 2002; Mathews, 1997; Owen, 2008; Parker, 2005; Unerman, Bebbinton, \& O’Dwer, 2007).

The accountant as a professional person will always in-touch with energy in their day-to-day activities in the corporation and organisation operations, and also as part of human on the planet. The accountant should take part responsible for saving and sustainable of energy as part of an agent of change to support and ensure as much as possible peoples available to access reliable, affordable, sustainable, and modern energy for all human better life in the future. Accountant perspective and more in-depth understanding of energy as part of the player to influence energy-saving and sustainable is a benefit for costs efficiency, corporation value and better quality life of humans on the planet. It believed that accountants are mostly unaware of how their skill could utilise in creating a heightened awareness of environmental sensitivity in the organisation (Ahmad, 2011), and (Lodhia, 2003) says that the lack of accountant competence in environmental matters and the voluntary nature of the existing environmental disclosure practices.

Accountants in developing countries, however, appear to be less reactive in creating change in their practices (Islam \& Dellaportas, 2011). But according to (Boyce, 2000; Degaan, 2014) it has been increasingly in developed countries, accepted that corporate social and environmental disclosure is crucial as it provides information on 
asset revaluations, cost analysis in energy use, investment appraisal, environmental liabilities and costs and benefits of environmental improvement programs, which relevant and necessary in corporate business making. In generally this study examines accountants' perspective in energy aspect in Indonesia. Therefore, this study addresses the questions is: What is accountants' perspective in energy aspects?.

Exploitation, production, and utilisation of energy always have bad and good economics value side impacts; it always correlates with economic activities for economic value benefits and environmental problem. Increasing of peoples growth in the world, use of land, growing technology and industries need more and more energy from time to time consumption by peoples and industry, "the steady increasing human population is a burden to world resources and leads to higher energy demand" (Ting, Mohammed, \& Choong, 2012).

Accountant perspective in energy and commitment as intellectual and professional personnel needed to influence corporation and peoples in the day to day operations. To promote and ensure their access to affordable, reliable, sustainable, and modern energy for corporation sustainable and better human life quality as SDGs framework concept for the development of countries in the future, is essential for an accountant. Accountant and top management commitment has been recognised as a vital element for an energy management program by various researchers (Gammon, 1986; Kofle, 1989; Smith, 1981) and (William, 1993) because top management and accountant must be primarily committed to resources allocation, both in terms of personnel and funds, according to (Capehart, Turner, \& Kennedy, 2006).

The objective of this research is "to capture particularly accountants' perspective in energy aspects correlated with energy sustainability and disclosure for development better future life quality as per SDGs framework concepts." Also, this study may contribute a new concept and practice in accounting and accountant perspective in energy sustainability.

\section{Literature Review}

\section{Definition}

Refer to SDGs frameworks concept, primarily goal number seven in Energy to ensure access to reliable, affordable, sustainable, and modern energy for all to develop and to build the country. Construction of harmony with the environment is goal achievement to increase the quality of human life and sustainability as the goal of countries in the world using SDGs framework concepts. Indonesia, as ones of the country, adopts and will be implementing the SDGs framework concept with unique culture and traditions. It is interesting to study the perspective of Accountant in Indonesia in the energy aspects in line with SDGs concept frameworks and achievement. Future more, sustainable energy and "the energy-environment threat concerns the degradation of the environment due to the production and use of energy, while the energy-social threat refers to global overpopulation" (Ting et al., 2012).

\section{Theoretical Foundation}

In the perspective of accountants in sustainable energy, this study using Stakeholder and Legitimacy theories. Stakeholder theory, in this study, is defined as any group or individual who can affect or is affected by the achievement of the firm's objectives. Freeman (1984) "The corporate planning and business policy model of the stakeholder concept focuses on developing and evaluating the approval of the corporate strategic decision by groups whose support is required for the corporation to continue to exist. The behaviour of various stakeholder groups is considered a constraint on the strategy that is developed by management to best match corporate resources with its environment" (Roberts, 1992). The spirit of stakeholder theory is harmonisation relationship between corporation and stakeholder for the benefit and sustainable both of them. Legitimation theory is defined as "organisations continually seek to ensure that they operate within the bounds and norms of their respective societies, that is, that they attempt to ensure that outside parties perceive their activities as being legitimate" (Deegan, 2006). Moreover, also legitimacy is "a general perception or assumption that the actions 
of an entity are desirable, proper, or appropriate within some socially constructed system of norms, beliefs, and definitions" (Suchman, 1995).

\section{Accountants' perspective in Energy}

This study applies four significant disclosure themes SDGs goals number seven as follow; 1). To ensure access to reliable, affordable, sustainable and modern energy for all; 2). Focuses on the subject of access to the modern cooking solution; 3). Access to reliable electricity, incentives for low-carbon energy in the electricity; 4). Moreover, intensity improvement of primary energy as the framework of concept for developing countries to increase the quality of human life in the future.

Accountant perspective and understanding of sustainable energy as SDGs framework concept to develop poor, emerging and developing countries is a significant contribution to support this program success to implementation. The accountant as a profession is always in-touch with economic activities as an agent of change and sustainability in the day-to-day economic activities and business process. "Sustainability has gained significant public and government attention, and many colleges recognised for their greening efforts. In many respects, the academy expected to be a leader in efforts to improve sustainability" (Dwyer, 2011).

\section{Access to modern energy for cooking solutions}

International Energy Agency (IEA) in the year 2015 reported that "Modern energy services are crucial to human well-being, and to a country's economic development, around 2.6 billion people are without clean cooking facilities. More than $95 \%$ of these people are either in sub-Saharan African or developing Asia and $84 \%$ are in rural areas, and around $38 \%$ global population lack clean cooking facilities". Peoples need to access modern energy for cooking with affordable price to increase their quality of life. Otherwise, "lack of energy awareness among the community could create difficulties for the energy conservation efforts and, subsequently, lead to energy wastage" $(\mathrm{Ng}$, Shakur, \& Choong, 2010).

"As energy demand and bills reduced for the poor, these households can acquire more and better energy services, as good as free up income to spend on satisfying other critical needs. Also, as utilities (notably in developing countries) improve their supply-side efficiency, they can provide more electricity to more households, thereby supporting increased access initiatives which are often an important stated objective of supply-side energy efficiency activities in developing countries" (Ryan \& Campbell, 2012).

\section{Access to reliable electricity}

All peoples in the modern life need electricity reliable electricity access to support their activities because most modern equipment and devices using electricity, and also human life without access to electricity it looks impossible in the digital world like now.

Reliable electricity is "power available during all regular service hours, with no outages exceeding two hours on a given day in the week before data collection" (Adair-Rohani et al., 2013).

Energy is the most fundamental reason the average people today live longer and improve their economic activity, Health, Education, and has greater access to information than the privileged elites of former time for better life quality. According to (Adair-Rohani et al., 2013) surveyed "only $35 \%$ of hospitals have reliable electricity access in Sub-Saharan African countries". It means "without commercial energy; modern civilisation would not exist" (Epstein, 2014).

\section{The incentive for low-carbon energy used}

Mostly energy exploitation and consumption for industries and household in the world still using non-renewable energy (fossil fuel), especially to produce electrical power. "The world's governments and business need to choose wisely and invest in low carbon energy, not the dirty fossil fuels of the past. Climate changes were striking faster than expected, but that the transition to clean energy was also accelerating. Climate change is happening much-much faster than expected" Ban Ki-moon, the UN SecretaryGeneral said. (The Guardian, 2015).

However, "Over and above the economic benefits from many of the instruments related to energy efficiency. Many proponents believe that other aspects of the program will yield economic 
benefits. As technologies mature and the rest of the world also moves toward more serious measures to tackle CO2 emission" (Wordsworth $\&$ Grubb, 2003). So now it is time to support the government to encourage investor building renewable energy. By given incentive, and also to promote industry and peoples using low-carbon energy for a better quality of life and reduce public costs, due environment damage and carbon problem for healthy of life, because "energy efficiency can have positive macroeconomic impacts. Increases in GDP and the cumulative benefits of the impacts mentioned above of improved trade balance (for fuelimporting countries), national competitiveness, and employment support. These are mainly indirect effects resulting from increased consumer spending and economy-wide investment in energy efficiency, as well as from lower energy expenditures" (Ryan \& Campbell, 2012).

\section{Improvement of Primary Energy}

Primary energy is an energy form found in nature that has not subject to any conversion or transformation process. Contained in raw fuels, and others forms of energy received as input to a system and also available to describe as is "the energy embodied in natural resources before undergoing any human-made conversions or transformation" (Kydes, 2011). Primary Energy resources examples include crude oil, coal, sunlight, wind, running river, ocean, and others. Primary energy is renewable and non-renewable energy. According to IEA reported that $80 \%$ of global energy consumption is base on fossil fuel and 32.3 GT of global energy-related $\mathrm{CO} 2$ emission in 2014.

Modern societies are increasing depend on reliable and secure energy supplies for economic growth and community prosperity. Energyrelated carbon dioxide $(\mathrm{CO} 2)$ emissions are the majority of global greenhouse gas (GHG) emission. We can reduce our emission by improving and changing energy consumption from fossil fuel to renewables. Benefits for industrial firms from improvements in energy efficiency include reductions in resources use and pollution, enhanced production and capacity utilisation, and less operation and maintenance, which leads to improved productivity and competitiveness (Ryan \& Campbell, 2012), and renewable power also plays a significant role in enhancing entrance by the poor to modern energy services (El-Ashry, 2014). Also, for the accountant, they play a role to reduce costs from energy used as a benefit for the company.

\section{Research Method}

Population and Sample of this study are the targets to obtain from accountants' resident in Indonesia with minimum have work experiences five years working in his (her) company from any profession and background of industries as an accountant. Accountants' respondent with any kind industries background and profession feedback targeted that their result of questioner's answer will achieve more objectives and heterogeneous about their perspective in energy aspects.

Survey questions of this study were using four scale Linkert methods with a total of seven questions as below: 1). Is the share of the population with access to reliable electricity, by urban/rural?; 2). Is the share of the population with access to reliable electricity, by urban/rural?; 3). Are implicit incentives for lowcarbon energy in the electricity sector?; 4). Is the rate of primary energy intensity improvement?; 5). Is sustainability Energy is crucial to disclose in the company annual report?; 6). Is sustainability Energy is crucial to attend to company sustainability?; 7). Is the energy calculation needed in the accounting system?

The answer of question clustered by two groups, first cluster of group question is to obtain accountants' understanding of perspective in energy aspects with answer scale; Very not understand, not understand, understand and very understanding. Second cluster respondent answer targeted is to know accountants' perspective crucial in energy aspects with the response of question scale; very not crucial, not crucial, crucial and very crucial. The total question of this survey are seven questions as a close question using four Linkert scales, and one additional question is an open question to obtain respondents opinion and the statement about aspects of energy perspective from the accountant side view. 
Research periods of this study were from May until June 2019, using two methods of survey, first by online survey using Google survey form with targeted 300 person accountant invited by email. Moreover, the second method is using manual survey targeted 20 person accountants by visiting respondents person to person to fill in the form and participate in this survey, online survey feedback from respondents automatically summary and grouped by Google system and manual survey summary and grouped by manual. Both answer feed-back by online and manual combined in one spread-sheet using Excel Microsoft program for future analyse using SPSS statistics software.

Data collected from respondents participated in this survey summarised into excel spreadsheet. Reliability is a term used to indicate the extent to which relatively consistent measurement results when the measurement repeated twice or more. Reliability is an index which indicates the extent to which the gauges can be trusted or relied upon (Agustine \& Kristaung, 2013). Reliability testing for this study using Cronbach's Alpha, to navigate and explore how far homogeneity measure of questions reflecting the same constructs as underlying. Research instruments a study said to be reliable if it has Cronbach's Alpha value ranging from 0,60 - 0,70. Basic of the decision are: (a). If Cronbach's Alpha value $>0,60$ it is mean Construct reliable; (b). If Cronbach's Alpha value $<0,60$ it is mean construct not reliable.

According to (Agustine \& Kristaung, 2013), the validity test is to measure the degree of the desired measuring construct to be measured. A validity test of this study using Pearson correlation test to see correlation score item and total score, using $r$ table two-tail testing significantly with significantly level $5 \%$ if $\mathrm{r}$ calculated $\geq \mathrm{r}$ table item tested is valid, and it is vise-versa (Priyatno, 2012).

\section{RESULT AND DISCUSSION}

After conducting a research study by online and manual to accountants' respondents participated in this research, the total sample we get is 42 samples, six samples rejected due above $80 \%$ uncompleted answers. Total available data to the process are 36 samples, from online respondent are 23 samples, and the rest are 13 samples collected by manual research method.

To make sure validity and Reliability data received from respondents tested using SPSS statistic program version 22. Pearson correlation tested result was between $0,470-0,711$ with $r$ table value is 0,320 , the outstanding value of $r$ calculated more than the value of $r$ table, this data valid for processing. Reliability test using Cronbach' alpha with alpha value is $8,43 \geq 0,80$ its means reliability of this data is highly reliable.

Based on data received valid and reliable tested, descriptive data analyses of the median is average 3 (understand and crucial), with modus 3 (understand and crucial) and also mean 3 (understand and crucial). In generally 51\% accountants' answer, they understand about energy and around $61 \%$ they tell energy is crucial for accountants' side view.

After conducting the survey content analysis, finding from accountants' perspective, the side view was gathered and discussed for each question in this survey research target.

\section{The share of the population with access to modern cooking solutions by urban/rural.}

Indonesian country have 13,466 islands (Bakosurtanal, 2015) as a big country with have many islands in the world, more of peoples in these countries still live in the villages and using conventional energy for cooking, modern cooking access only enjoyed by people who live in the city have access to electricity provided by government as monopoly by semi-state-owned namely Perusahaan Listrik Negara (PLN). Mostly peoples live in the Small Island and villager still not available to access electricity for modern cooking.

Base on the sample we collected $55 \%$ understand about energy aspects, $24 \%$ does not understand, and $20 \%$ very understand, no one of the accountants' not understands about energy $(0 \%)$. The accountants' said $70 \%$ energy is crucial aspects for an accountant, $25 \%$ choose very important, and $5 \%$ said not crucial, and no one of accountant said that energy is very not crucial $(0 \%)$.

The share of the populace with access to reliable electricity by urban/rural. 
According to Indonesian Geology, Survey and spatial government body, Indonesian countrywide are $5,180,053 \mathrm{Km}^{2}$ consists of $1,922.570 \mathrm{Km}^{2}$ lands vast and $3,257,483 \mathrm{Km}^{2}$ spatial by an ocean (Bakosurtanal, 2015). Most of the Indonesian people's lives in the village and more of them also currently no access to electricity. Accountants' perspective for the above questions $62 \%$ answer understands, $29 \%$ very understand, 9\% not understand and $0 \%$ answer very not understand. Crucial of Energy for accountants' of the above questions is $56 \%$ said crucial, $41 \%$ very crucial and only $3 \%$ choose not crucial, and the rest is answer $0 \%$ or very no crucial.

\section{Implicit incentives for low-carbon energy in the electricity sector}

Indonesia is a big country with big consumes energy for industries, home, and other people activities. Mostly electricity power and industry consume currently using fossil fuel, or nonrenewable energy have a severe negative impact on life and also expensive for poor people. Encourage of implicit incentives for industry and investor using clean and renewable energy others way to get cheap, clean and renewable energy.

Accountant perspective for the above subject is $53 \%$ answer understand, $22 \%$ very understand, $22 \%$ not understand, and 3\% answer decidedly not understand. Majority of accountants' said it crucial is $64 \%, 30 \%$ choose very crucially, $6 \%$ not important and $0 \%$ answer it is decidedly not crucial.

\section{The rate of primary energy intensity improvement}

Indonesia, as a long coastal country, has vast sea, all year have sunshine, wind, and mountains it is productive in clean and renewable energy resources for prime energy to develop. If accountant available to influence management and corporation to convert fossil-energy used to primary energy, it is a significant benefit will achieve from costs reduction of the company operation and clean energy for community health. Accountant perspective of primary energy intensity improvement is $54 \%$ answer understand, $32 \%$ very understand, $14 \%$ not understand and $0 \%$ answer that they very not understand. The crucial side of accountants' perspective is $64 \%$ said crucial, $34 \%$ very crucial, $2 \%$ said it is not crucial, and no one of them mentioned it is decidedly not crucial $(0 \%)$.

\section{Sustainability Energy is crucial to disclose in the company annual report.}

The company cannot operate without support by energy, how much company consume the energy it depends on small and big of company size and activities, and company sustainability without energy it is maybe impossible.

Base on a sample of research study, $44 \%$ accountants' said understand, $40 \%$ very understand, $16 \%$ not understand, and no one chooses very no understand $(0 \%)$. Crucial of disclose sustainability in the company annual report accountants' said $58 \%$ crucial, $40 \%$ very crucial, $2 \%$ said no crucial and no one choose it is decidedly not crucial $(0 \%)$.

\section{Sustainability Energy is crucial to attend to company sustainability}

Mostly of accountants' answer the above question is understand $54 \%$, very understand $36 \%, 9 \%$ answered not understand and only $1 \%$ answer very not understand. Crucial of sustainable energy to attention by an accountant for company sustainability is $61 \%$ answer crucial, $37 \%$ very crucial, $2 \%$ not crucial and only $0 \%$ answer very not crucial.

\section{Energy calculation needed in the accounting system}

Answer from accountants' regarding above is $35 \%$ said to understand, $39 \%$ very understand, $25 \%$ not understand and only $1 \%$ said very not understand. However, accountants' answer it is crucial is $58 \%, 39 \%$ choose very crucially, $4 \%$ said no crucial and $0 \%$ said very not crucial.

\section{Discussion}

According to 36 samples of research answer received of this study, in generally accountants' understand about energy and answer crucial of energy for an accountant as professions. Energy is one of the components of the costs in company operations, without energy company cannot operating and sustainable. Accountants' understand about energy is strategies playing role and position to encourage management and company using energy efficiencies by measure 
energy used by the company and disclose into company annual reports.

Mostly of accountants answer that energy is crucial and urgent to implementation in accounting systems, may it is another way to push government and investor as mandatory to converting fossil fuel to clean and cheap of renewable energy have abundant resources in Indonesia from sea to mountain all potential to explore for a better quality life in the future.

\section{Conclusion}

Accountants' participated in this study was a senior position with experiences more than five years above came from all around Indonesian corner and also from Singapore and Malaysian country, previous target this study only Indonesian accountants but in the facts, some respondent participating by online survey come from Malaysia and Singapore country. Mostly of respondents' enthusiasm and positive suggestions from their side view to see energy as basic needs as human and as accountants' profession.

According to respondent suggestion "as accountant perspectives in energy security, it is vital for our life. Energy has a significant playing role for our life and to rotating economics cycle, and we are as accountant parts of them. Because energy security as a benchmark of country success to increase their people's economics and life prosperous". Because "energy security responsibility all of us, including accountant in this cycle. So, everybody should have a responsibility to maintain and devolve of concept and action plan to encourage sustainability energy" and "accountant should have a contribution to compile accounting information system for taking a decision and counting of energy used."

Otherwise, some accountants' knowledge about energy is less understand, but they said: "energy issues need to disclose in the company annual report." Because "energy resources deposit will decrease from time to time, and in the end, energy will deficit and demand will increase, and price increases also, and accountant should smart to see the treats of energy crisis in the future, and from now accountant need to concern about that and recording energy expenses in the accounting system".

Because "sustainability of energy very important, the accountant should encourage using energy with effective, and as efficient as possible. The sustainability energy needs to disclose by the company in the annual report". Therefore, all aspects of life "depend on energy, sustainable energy for sustainability life and company, so us, as an accountant need to help the company in the preparing of company reporting activities related to energy and environments in used energy resources into a financial report. Because, without energy, the company will not be available to sustainable, without company, may accountants' profession will collapse", and "energy available to support sustainability developments" because " energy is vital for company operating and sustainability" and in the end accountants' participation in energy perspective "very important, because we should maintain our planet for our next generations".

Some limitation noted in this study is period of study to short only two months from May to June 2019, and low respondents participated in this study need to develop for future research, and also minimal literature of accounting correlation with energy as a reference for this study also noted.

Future research in energy aspects correlation with an accountant as a profession is exciting and still broad, i.e., to see how energy influence costs of company operations, how energy encourage revenue for company sustainability and green energy for future resources of company operations. Moreover, costs impact on social and community from using fossil-fuel to challenge of converting to green energy, and how energy influence economic value, and also accounting for energy standard-setting to anticipate a change of energy policy by regulation as mandatory or volunteer and social culture in the future, because of culture and technology change in the future.

Accountants' perspective in energy sustainability knowledge some still poor and do not care about energy security as they statement say; this is "no direct correlation of accountants' as a profession with energy security. So accountant no need to encourage and participating to implementing security energy" it is a challenge for us as accountant as profession 
and human on the planet to make us better understand about energy, because our life depends on energy, without energy may no more company sustainable in future and also maybe accountant as profession will lose in the earth.

\section{Reference}

Adair-Rohani, H., Zukor, K., Bonjour, S., Wilburn, S., Kuesel, A. C., Hebert, R., \& Fletcher, E. R. (2013). Limited electricity access in health facilities of sub-Saharan Africa: a systematic review of data on electricity access, sources, and reliability. Global Health: Science and Practice, 1(2), 249-261. https://doi.org/10.9745/GHSP-D13-00037.

Agustine, Y., \& Kristaung, R. (2013). Metode Penelitian Bisnis dan Akuntansi (1st ed.). Jakarta: Dian Rakyat.

Ahmad, N. (2011). Corporate environmental responsibility and environmental disclosure: The perception of Libyan managers in industrial companies. The Journal of International Business and Economic Affair, 2(1), 35-32. Retrieved from www.ecoena.ca/f/JIBEA_Volume_2_-_ECO-

ENA_Inc.pdf.

Ahmad, N. S., \& Gao, S. S. (2007). Changes, problems and challenges of accounting education in Libya. Accounting Education, 13(3), 365-390. https://doi.org/10.1080/09639280420002738 25.

Ascui, F., \& Lovell, H. (2011). As frames collide: making sense of carbon accounting. Accounting, Auditing \& Accountability Journal, 24(8), 978-999. https://doi.org/10.1108/09513571111184724

Bakosurtanal. (2015). Big serahkan peta nkri kepada kemenkokesra. Retrieved July 15, 2018 , from http://www.bakosurtanal.go.id/beritasurta/show/big-serahkan-peta-nkri-kepadakemenkokesra.

Boyce, G. (2000). Public discourse and decision making. Accounting, Auditing \& Accountability Journal, 13(1), 27-64. https://doi.org/10.1108/09513570010316135
Capehart, B. L., Turner, W. ., \& Kennedy, W. (2006). Guide to Energy Management (5th ed.). Lilbuen, GA: Fairmont Press.

Deegan, C. (2006). Financial Accounting Theory (2nd ed.). Australia: McGraw-Hill.

Dwyer, C. (2011). The Relationship between Energy Literacy and Environmental Sustainability. Low Carbon Economy, 02(03), 123-137. https://doi.org/10.4236/lce.2011.23016.

El-Ashry, M. (2014). Energy, Climate Change and Global Sustainability. Environmental Policy and Law, 44(1-2).

Epstein, A. (2014). The moral case for fossil fuels (1st ed.). USA: Penguin Group USA LLC.

Freeman, R. (1984). Strategic Management: a stakeholder approach (1st ed.). Pitman Publishing Imprint.

Gammon, R. B. (1986). Energy Management in Building. In "The Australian Approach to energy management "in Sherratt (AFC Editio). Hutchinson, London.

Gray, R., Bebbington, J., \& Walters, D. (1993). Accounting for Environment. London: Paul Chapman [for] ACCA, The Chartered Association of Certified Accountants.

Gray, Rob. (2002). The social accounting project and Accounting Organizations and Society Privileging engagement, imaginings, new accountings and pragmatism over critique? Accounting, Organizations and Society, 27(7), 687-708. https://doi.org/10.1016/S03613682(00)00003-9.

Gunawan, J., Djajadikerta, H., \& Smith, M. (2009). An examination of corporate social disclosures in the annual reports of Indonesia listed companies. Asia Pacific Centre for Environmental Accountability Journal, 15(1), 13-36. Retrieved from https://www.unisa.edu.au/siteassets/episerve r-6-

files/global/business/centres/cags/docs/apcea /apcea_2009_151_gunawan_djajadikerta_s mith.pdf.

Gyberg, P., \& Palm, J. (2009). Influencing households' energy behaviour-how is this done and on what premises? Energy Policy, 
37(7), $2807-2813$. https://doi.org/10.1016/j.enpol.2009.03.043.

Islam, M., \& Dellaportas, S. (2011). Perceptions of corporate social and environmental accounting and reporting practices from accountants in Bangladesh. Social Responsibility Journal, 7(4), 649-664. https://doi.org/10.1108/1747111111117519.

Kofle, J. T. (1989). The energy management program at Southwire. In Managing Energy Resources in Times of Dynamic Change. Lilburn GA: Fairmont Press.

Krajnic, D., Lukman, R., \& Glavic, P. (2008). Approaches to sustainable energy consumption patterns. In Energy Management and Conservation Handbook (in Kreith). Boca Raton, FL: Taylor \& Francis Group.

Kydes, A. (2011). Primary Energy. Retrieved June 5, 2015, from http://www.eoearth.org/ view/article/ 155350 .

Lodhia, S. K. (2003). Accountants' Responses To The Environmental Agenda In A Developing Nation: An Initial And Exploratory Study On Fiji. Critical Perspectives on Accounting, 14(7), 715-737. https://doi.org/10.1016/S10452354(02)00190-9.

Mathews, M. R. (1997). Twenty-five years of social and environmental accounting research. Accounting, Auditing \& Accountability Journal, 10(4), 481-531. https://doi.org/10.1108/EUM000000000441 7.

Narbel, P. A. (2014). Energy Technologies and Economics (1st ed.). Switzerland: Springer International Publishing.

Ng, S. Y., Shakur, E. S. A., \& Choong, W. W. (2010). Energy Conservation opportunities in Malaysian University. Malaysian Journal and Real Estate, 5(1), 26-35.

Owen, D. (2008). Chronicles of wasted time? A personal reflection on the current state of, and future prospects for, social and environmental accounting research. Accounting, Auditing \& Accountability Journal, 21(2), 240-267. https://doi.org/10.1108/09513570810854428
Parker, L. D. (2005). Social and environmental accountability research: A view from the commentary box. Accounting, Auditing \& Accountability Journal, 18(6), 842-860. https://doi.org/10.1108/0951357051062773.

Priyatno, D. (2012). Belajar Cepat Olah Data Statistik dengan SPSS (1st ed.). Jogjakarta: Penerbit Andi.

Roberts, R. W. (1992). Determinants of corporate social responsibility disclosure: An application of stakeholder theory. Accounting, Organizations and Society, 17(6), 595-612. https://doi.org/10.1016/03613682(92)90015-K.

Roth, H. P. (2008). Using cost management for sustainability efforts. Journal of Corporate Accounting \& Finance, 19(3), 11-18. https://doi.org/10.1002/jcaf.20381.

Ryan, L., \& Campbell, N. (2012). Spreading the net: The multiple benefits of energy efficiency improvements. https://doi.org/10.1787/20792581.

Sheau Ting, L., Hakim Bin Mohammed, A., \& Wai Choong, W. (2012). Proposed implementation strategies for energy sustainability on a Malaysian university campus. Business Strategy Series, 13(5), 208-214. https://doi.org/10.1108/17515631211264087

Smith, C. B. (1981). Energy Management Principles: Applications, Savings. Oxford, U.K.: Pergamon Press.

Suchman, M. C. (1995). Managing Legitimacy: Strategic and Institutional Approaches. The Academy of Management Review, 20(3), 571-610. https://doi.org/10.2307/258788.

Tempo.co. (2015). Krisis Energi Ancam Indonesia, Ini yang Harus Dilakukan. Retrieved May 25, 2019, from https://bisnis.tempo.co/read/663691/krisisenergi-ancam-indonesia-ini-yang-harusdilakukan/full\&view $=$ ok.

Tempo.co. (2019). RI Butuh Rp 1.000 Triliun Kejar Energi Terbarukan di 2025. Retrieved December 21, 2019, from https://bisnis.tempo.co/read/1284826/ributuh-rp-1-000-triliun-kejar-energiterbarukan-di-2025. 
The Guardian. (2015). Urges governments to invest in low carbon energy. Retrieved June 3, 2019, from http://www.theguardian.com/environment/2 015/jun/02/ban-ki-moon-urgesgovernments-invest-low-carbon-energy.

Unerman, J., Bebbinton, J., \& O'Dwer, B. (2007). Sustainability Accounting and Accountability. London: Routledge.

WEO. (2012). World Energy Outlook 2012. Retrieved June 5, 2019, from http://www.worldenergyoutlook.org/publicat ions/ weo-2012/.

William, M. A. (1993). Initiating, Organizing, and managing energy management programs" in Turner. In W. C. Turner (Ed.), Energy Management Handbook. Lilburn GA: Fairmont Press.

Wordsworth, A., \& Grubb, M. (2003). Quantifying the UK's incentives for low carbon investment. Climate Policy, 3(1), 7788. https://doi.org/10.3763/cpol.2003.0308. 